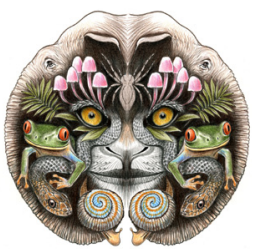

ISSN

Online 0974-7907

Print 0974-7893

OPEN ACCESS
Caralluma R.Br. (sensulato) has been usually accepted to include about 120 taxa, with a wide African, Asian and southeastern European distribution (Mabberley 1993). It belongs to the subtribe Stapeliinae (tribe Ceropegiae, subfamily Asclepiadoideae and family Apocynaceae), which has its centre of origin in East Africa (Meve \& Liede 2004). The genus comprises xerophytic succulent herbs, represented by 13 species and eight varieties in India. Of these, eight species and seven varieties are endemic to peninsular India (Karuppusamy et al. 2013). The genus Caralluma is closely allied to Boucerosia but differs by having flowers arising in the axils of rudimentary leaves all along the distal portion of the stem. The type species of the genus Caralluma is C. adscendens (Roxb.) Haw., a species originally described from peninsular India (Meve \& Liede 2002). Among them, 13 species and five varieties are presented in India (Jagtap \& Singh 1999). Recently, a few new taxa have been described from India including Caralluma moorei Aditya (Aditya 2011a), C. bicolor Ramach. et al. (Ramachandran et al. 2011), C. sarkariae var. longipedicellata Aditya (Aditya 2011b), C. stalagmifera var. intermedia Karuppusamy \& Pullaiah and C. stalagmifera var. longipetala Karuppusamy \& Pullaiah (Karuppusamy \& Pullaiah 2007).

Caralluma adscendens is a first described Indian stapeliad that has found greater variations among the taxa which has attracted several taxonomists to work out the complexities of this group (Karuppusamy et al. 2013). Variability in the floral morphology of $C$. adscendens is higher than what is typically found in other widespread allied species and has, therefore, hampered a sound taxonomic treatment. The increasing availability of

\section{NOTES ON CARALLUMA ADSCENDENS (ROXB.) HAW. VAR. ATTENUATA (WIGHT) GRAV. \& MAYUR. (APOCYNACEAE: ASCLEPIADOIDEAE)}

\author{
K.M. Prabhu Kumar ${ }^{1}$, U.C. Murshida ${ }^{2}$, Binu Thomas ${ }^{3}$, \\ Satheesh George ${ }^{4}$, Indira Balachandran ${ }^{5}$ \& \\ S. Karuppusamy ${ }^{6}$ \\ ${ }^{1,2,5}$ Centre for Medicinal Plants Research, Arya Vaidya Sala, Kottakkal, \\ Malappuram, Kerala 676503, India \\ ${ }^{3}$ PG Department of Botany, Deva Matha College, Kuravilangad, \\ Kottayam, Kerala 686633, India \\ ${ }^{4}$ Department of Botany, St. Joseph's College Devagiri, Calicut, Kerala \\ 673008 , India \\ ${ }^{6}$ Department of Botany, The Madura College (Autonomous), Madurai, \\ Tamilnadu 625011, India \\ ${ }^{1}$ prabhumkrishna@gmail.com (corresponding author), ${ }^{2}$ umurshi@ \\ gmail.com, ${ }^{3}$ binuthomasct@gmail.com, ${ }^{4}$ george.satheesh@gmail. \\ com, ${ }^{5}$ indirapa@hotmail.com, ${ }^{6}$ ksamytaxonomy@gmail.com
}

plant material has demonstrated intraspecific variability, where almost every population shows its own features (as the many illustrations published by Gravely \& Mayuranathan (1931) show). Especially with regard to frequently occurring differences in corolla structure, size, ciliation, striation, color variation, corona structure and position of insertion of pollinarium have already been established for taxonomic and systematic significance in stapeliad species. However, several distinct tendencies that support intraspecific differentiation have to be considered for delimitation of taxonomic ranks. Inner coloration of the corolla surface is predominantly purple, but creamy yellow coloration is found in C. adscendens var. gracilis. Dense purple-red transverse stripes or streaks are found in all the six varieties of $C$. adscendens but each variety has different patterns and amount of striation (Karuppusamy \& Pullaiah 2013). Many authors have already presented the variations among

DOI: http://dx.doi.org/10.11609/JoTT.03523.6282-6

Editor: Ravi Prasad Rao, Sri Krishnadevaraya University, Anantapur, India.

Date of publication: 26 August 2014 (online \& print)

Manuscript details: Ms \# 03523 | Received 09 February 2013 | Final received 15 July 2014 | Finally accepted 07 August 2014

Citation: Kumar, K.M.P., U.C. Murshida, B. Thomas, S. George, I. Balachandran \& S. Karuppusamy (2014). Notes on Caralluma adscendens (Roxb.) Haw. var. attenuata (Wight) Grav. \& Mayur. (Apocynaceae: Asclepiadoideae). Journal of Threatened Taxa 6(9): 6282-6286; http://dx.doi.org/10.11609/JoTT.o3523.6282-6

Copyright: (c) Kumar et al. 2014. Creative Commons Attribution 4.0 International License. JoTT allows unrestricted use of this article in any medium, reproduction and distribution by providing adequate credit to the authors and the source of publication.

Funding: None.

Competing Interest: The authors declare no competing interests.

Acknowledgements: The authors are thankful to the authorities of Arya Vaidya Sala, Kottakkal.
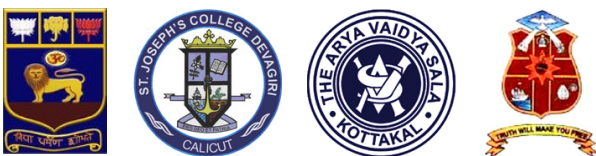
the succulent stapeliads of Caralluma groups in India (Plowes 1995; Aditya 2009; Plowes 2011; Karuppusamy et al. 2012). The present communication is aimed at revealing the floral variations among the Caralluma adscendens var. attenuata in Tamil Nadu State.

Caralluma adscendens (Roxb.) R. Brown var. attenuata (Wight) Gravely \& Mayuranathan in Bull. Madr. Govt. Mus. n.s. N.H. 4(1): 13. 1931; S.R. Srinivasan in A.N. Henry et al. Fl. Tamil Nadu Anal. 2: 81. 1987; Gilbert in Bradleya 8: 11. 1990; Plowes in Haseltonia 3: 52. 1995; Jagtap \& Singh in Fasc. Fl. India 24: 194. 1999; Meve \& Leide in Plant Syst. Evol. 234: 200. 2002. C. attenuata Wight, Ic. PI. Ind. Orient. 4(1): 15. t. 1268. 1848. Type: tab. 1268 of protologue based on material from India; Hooker f. Fl. Brit. India 4: 76.1883; Gamble FI. Pres. Madras 2: 861.1923.

Common names: Kallimulaiyan, Mankulli, Iluvaan, Pulichampirandai (Tamil).

Succulent herb: vegetative stem fleshy, $60-65 \mathrm{~cm}$ high and $6.8 \mathrm{~cm}$ width, highly branched with tapering end at the tip. Branches are quadrangular, angle rounded, dark green in the base and paler purplish colored at the tip, fertile apical portion very slender. Leaves caducous, reduced to conical teeth which are arranged in four ribs, $2 \mathrm{~cm}$ at base and $2-2.5 \mathrm{~cm}$ apart from each other. Inflorescence is cyme. Flowers single or 2-3, axils on minute leaf axils, sides of stem; bracts minute, lanceolate, 1 or 2 , pedicillate $0.3 \mathrm{~mm}$ in length and $0.2 \mathrm{~mm}$ in width and it is glabrous, pendulous, bisexual and complete. Calyx is divided to base $0.25 \times 0.1 \mathrm{~mm}$, ovate or lanceolate, acuminate at apex, fleshy, glabrous and brownish-green in colour. Corolla bud $1.0-1.4 \mathrm{~cm}$ long, tubular, constriction in above the middle with valvate aestivation. Corolla $0.9 \times 0.3 \mathrm{~mm}$ in diameter, glabrous at the base and pubescent at the tip, purple in color, in the inner side of the lower portion a yellow brown ornamentation is present. Corona biseriate, ca. $1 \mathrm{~mm}$ in long, broad at the base; inner corona $0.2 \mathrm{~mm}$ in long, incumbent on anthers, basally united with outer corona. Anther $0.5 \mathrm{~mm}$ long, yellowish, basally united with inner surface of the middle corona, swollen. Pollen yellow, round, waxy attached by the reddish brown caudicle. Gynostegium $1 \mathrm{~mm}$ long; stigma cap is star pentagonal. Follicle cylindrical with tapering ends and green color with black stripes present, $8.4 \mathrm{~cm}$ in long and $2.3 \mathrm{~cm}$ in width (Image 1 ).

Habitat: Dry deciduous forests and scrub jungles. The materials for the present study were collected from various areas of Tamil Nadu state (Table 1).

Flowering \& Fruiting: Throughout the year.

Distribution: Peninsular India and Sri Lanka.
Medicinal uses: Anti-hyperglycaemic herb used for the treatment of migraine, urinary trouble, chest pain and general weakness of the body. The stem is also used for preparing chutney (Reddy et al. 2010). C. attenuata extract prevents increase in blood glucose levels significantly after glucose administration (Kumar et al. 2011). The Paliyar tribe used $C$. adscendens as as a remedy for diabetes, lung diseases, indigestion, kidney stone, epilepsy, skin diseases and so on. A paste prepared from $20 \mathrm{~g}$ of the whole plant along with ghee and an equal quantity of black gram, coriander, pepper and cumin seeds if taken orally once a week cures vomiting, indigestion and reduces body heat (Maruthupandian \& Mohan 2010). The methanol extract of $C$. adscendens var. attenuata shows significant anti-oxidant, anti-inflammatory, anti-diabetic and antimicrobial activities, which could be used as a potential source of pharmaceutical materials (Madhuri et al. 2010).

Variation study: The detailed morphometric and reproductive characters were observed from the field and tabulated (Table 2). The morphological variations among C. adscendens var. attenuata showed four different morphological classes which are sporadically distributed in different parts of Tamil Nadu (Table 1). Habitat is strongly attributed to its growth forms due to the availability of nutrients and light that greatly influence the growth habit of succulents. Caralluma

Table 1. Localities and morphological variants of Caralluma adscendens var. attenuata (Wight) Grav. \& Mayur. in Tamil Nadu.

\begin{tabular}{|c|c|c|c|c|}
\hline & Locality & GPS location & $\begin{array}{l}\text { Voucher } \\
\text { number(s) }\end{array}$ & $\begin{array}{l}\text { Morpholo- } \\
\text { gical group }\end{array}$ \\
\hline 1 & $\begin{array}{l}\text { Madhukkarai, } \\
\text { Coimbatore District }\end{array}$ & $\begin{array}{c}10^{\circ} 90.283^{\prime} \mathrm{N} \\
\& 76^{\circ} 97.102^{\prime} \mathrm{E}\end{array}$ & $\begin{array}{l}\text { CMPR 7145, } \\
7252,7261\end{array}$ & II \\
\hline 2 & $\begin{array}{l}\text { Palnihiils, Dindigul } \\
\text { District }\end{array}$ & $\begin{array}{c}10^{\circ} 24.425^{\prime} \mathrm{N} \\
\& 77^{\circ} 50.320^{\prime} \mathrm{E}\end{array}$ & $\begin{array}{l}\text { SK 2316, } \\
2326\end{array}$ & IV \\
\hline 3 & $\begin{array}{l}\text { Marudhamalai, } \\
\text { Coimbatore District }\end{array}$ & $\begin{array}{c}11^{\circ} 05.420^{\prime} \mathrm{N} \\
\& 76^{0} 25.534^{\prime} \mathrm{E}\end{array}$ & SK 1752 & II \\
\hline 4 & $\begin{array}{l}\text { Kolli Hills, Namakkal } \\
\text { District }\end{array}$ & $\begin{array}{c}11^{\circ} 02.376^{\prime} \mathrm{N} \\
\& 78^{\circ} 21.837^{\prime} \mathrm{E}\end{array}$ & $\begin{array}{l}\text { SK 2135, } \\
2144\end{array}$ & III \\
\hline 5 & $\begin{array}{l}\text { Sirumalai, Dindigul } \\
\text { District }\end{array}$ & $\begin{array}{c}10^{\circ} 24.226^{\prime} \mathrm{N} \\
\& 78^{\circ} 12.930^{\prime} \mathrm{E}\end{array}$ & $\begin{array}{l}\text { SK 1643, } \\
1651,1655\end{array}$ & 1 \\
\hline 6 & $\begin{array}{l}\text { Thirumayam, } \\
\text { Pudukottai District }\end{array}$ & $\begin{array}{l}10^{\circ} 21.472^{\prime} \mathrm{N} \\
\& 78^{\circ} 75.052^{\prime} \mathrm{E}\end{array}$ & $\begin{array}{l}\text { SK 2254, } \\
2263,2272\end{array}$ & III \\
\hline 7 & $\begin{array}{l}\text { Tiruppatthur, } \\
\text { Sivaganga District }\end{array}$ & $\begin{array}{c}10^{\circ} 11.066^{\prime} \mathrm{N} \\
\& 78^{\circ} 49.210^{\prime} \mathrm{E}\end{array}$ & $\begin{array}{l}\text { SK 2178, } \\
2183\end{array}$ & II \\
\hline 8 & $\begin{array}{l}\text { Oddanchatram, } \\
\text { Dindigul District }\end{array}$ & $\begin{array}{c}10^{\circ} 48.127^{\prime} \mathrm{N} \\
\& 77.75 .039^{\prime} \mathrm{E}\end{array}$ & $\begin{array}{c}\text { SK 1592, } \\
1598\end{array}$ & 1 \\
\hline 9 & $\begin{array}{l}\text { Barigam, } \\
\text { Dharmapuri District }\end{array}$ & $\begin{array}{c}11^{\circ} 93.301^{\prime} \mathrm{N} \& \\
77.98 .528^{\prime} \mathrm{E}\end{array}$ & SK 1720 & IV \\
\hline 10 & $\begin{array}{l}\text { Kolli Hills, Namakkal } \\
\text { District }\end{array}$ & $\begin{array}{c}11^{0} 24.852^{\prime} \mathrm{N} \& \\
78^{0} 33.870^{\prime} \mathrm{E}\end{array}$ & $\begin{array}{c}\text { SK 1542, } \\
1564\end{array}$ & II \\
\hline
\end{tabular}




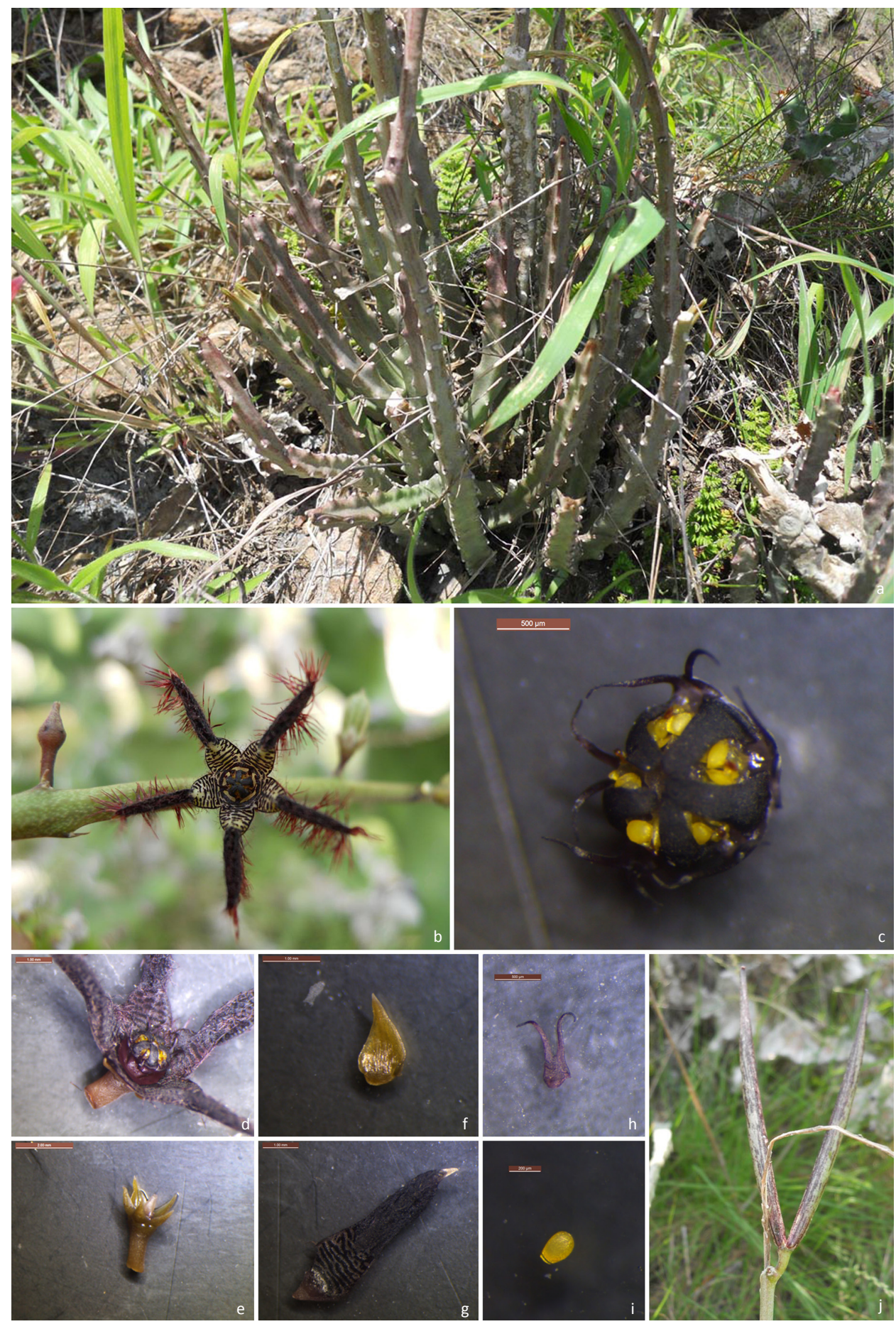

Image 1. Caralluma adscendens (Roxb.) Haw. var. attenuata (Wight) Grav. \& Mayur.

A - habit; B - close up of flower; C - corona-surface view; D - corona-side view; E - calyx; F - calyx lobe; G - corolla lobe; H - outer corona; I - pollinium; J - follicle (@ K.M. Prabhu).

depends on the substratum and also its associates for their usual growth (Images $2 \mathrm{~A}-\mathrm{D}$ ). Mostly they grow on open rocky or soil substratum but in many places they are associated with thorny bushes like Prosopis juliflora (Sw.) DC., Catunaregam spinosa (Thunb.)
Tirveng., Canthium coromandelicum (Burm. f.) Alston, Euphorbia antiquorumL.,Commiphora berryi (Arn.) Engl., Dichrostachys cinerea (L.) Wight \& Arn., Barleria buxifolia L., B. noctiflora L.f. etc. The succulent quadrangular stem of the taxon may differ in round angle and acute 
Table 2. Vegetative and reproductive variations in Caralluma adscendens var. attenuata (Wight) Grav. \& Mayur. in Tamil Nadu

\begin{tabular}{|c|c|c|c|c|}
\hline Characters & Group- I & Group- II & Group- III & Group- IV \\
\hline Habitat & open bush & on rocky substratum & shaded under thorny bushes & road sides \\
\hline Acuteness of stem angle & rounded & slightly sharp angles & slightly elevated & acute angles \\
\hline Inflorescence & terminally branched & unbranched & unbranched & unbranched \\
\hline Number of flowers in axils & single & single & single or biflowered & two or three \\
\hline Size of corolla & $0.8 \times 0.7 \mathrm{~mm}$ dia. & $0.5 \times 0.3 \mathrm{~mm}$ dia. & $0.9 \times 0.6 \mathrm{~mm}$ dia. & $0.8 \times 0.6 \mathrm{~mm}$ dia. \\
\hline Hairiness of corolla margin & purplish red, dense & purplish, sparse & purplish-yellow, very sparse & absent \\
\hline Striation on corolla lobe & above half dark purple & above half pale purplish & above half purplish dotted & pale pinkish \\
\hline Shape of outer corona & recurved & slightly recurved & semi-erect tips & recurved tips \\
\hline Colour of outer corona & dark purplish & reddish-purple & pale pinkish & pale yellowish \\
\hline Colour of inner corona & dark purplish & purple & pinkish & yellowish \\
\hline Colour of pollinaria & orange reddish & yellowish & pale yellowish & pale yellowish \\
\hline Rate of fruit set & $15 \%$ & $12 \%$ & $16 \%$ & $12 \%$ \\
\hline Length of follicles & $10 \mathrm{~cm}$ long & $8.2 \mathrm{~cm}$ & $7.4 \mathrm{~cm}$ & $8.5 \mathrm{~cm}$ \\
\hline Colour of the follicle & purplish streaks & purple blotches & whitish molten & creamy \\
\hline Length of seed hairs & $3.5 \mathrm{~cm}$ & $3.2 \mathrm{~cm}$ & $2.5 \mathrm{~cm}$ & $2.9 \mathrm{~cm}$ \\
\hline Colour of the seed hairs & cottony white & creamy white & pale yellowish & pale yellowish \\
\hline Number of seeds in mature pod & 52 & 39 & 46 & 41 \\
\hline
\end{tabular}

angle in that most of the var. attenuata have a round angle, but a few populations were observed to have acute angle stems in the foothills of Palni and Barigam of Dharmapuri District. The colour of the stem is also varied in different populations, usually purple streaks on the stem and it is more concentrated during summer seasons. In many populations of this taxon there are dense purple blotches near the leaf protuberance and less in internodal regions. Floral variations are common among the succulent Apocynaceae in respect of their color, hairiness, striation pattern on corolla lobes, position of insertion of pollinarium, colour of pollen masses, coronal pattern, follicle morphology, rate of fruit setting, number of seeds per pods, seed morphology, seed hair color etc. (Karuppusamy et al. 2013).

A range of floral variations has been observed in the $C$. adscendens var. attenuata in Tamil Nadu State alone in the present study (Table 2). Bruyns (1989) has drawn attention to the very great similarity among these varieties - fimbriata from India, Caralluma subulata from Arabia and Caralluma dalzielii from West Africa. This could be taken to indicate that the two groups such as round and acute angle varieties merit formal recognition at least as subspecies. The status of the varieties within C. adscendens seems more questionable as Gravely and Mayuranathan indicated that intermediates are apparently common (Gilbert 1990). The present accounts indicate that $C$. adscendens var. attenuata is a variable and widely distributed species, with at least four distinct morphoforms being recognized. Gravely \& Mayuranathan (1931) have suggested the use of classification of varieties under $C$. adscendens partly in flower morphology and partly in stem morphology. But these varieties are unable to be held as herbarium specimens, because these are succulent genera. There is considerable floral (but also vegetative) variability in C. adscendens var. attenuata, quite often even between plants of single populations, but almost always between different populations. These circumstances have stimulated many taxonomists and regional florists to describe morphotypes, ecotypes or varieties or forms. Even though in many places overlapping populations are exhibited among the taxon and also with other varieties of the species, Karuppusamy et al. (2013) suggested that the variable forms of Indian Caralluma with the complex taxonomy still needs to be answered because this complexity has never been explored as a whole (Images $2 \& 3)$.

\section{References}

Aditya, S. (2009). Habitat colour variance in Caralluma sarkariae Lavranos \& Frandsen. Asklepias 105: 5-8.

Aditya, S. (2011a). Caralluma moorei Aditya sp.nova A new species from East coastal India. Asklepias 110: 3-10. 


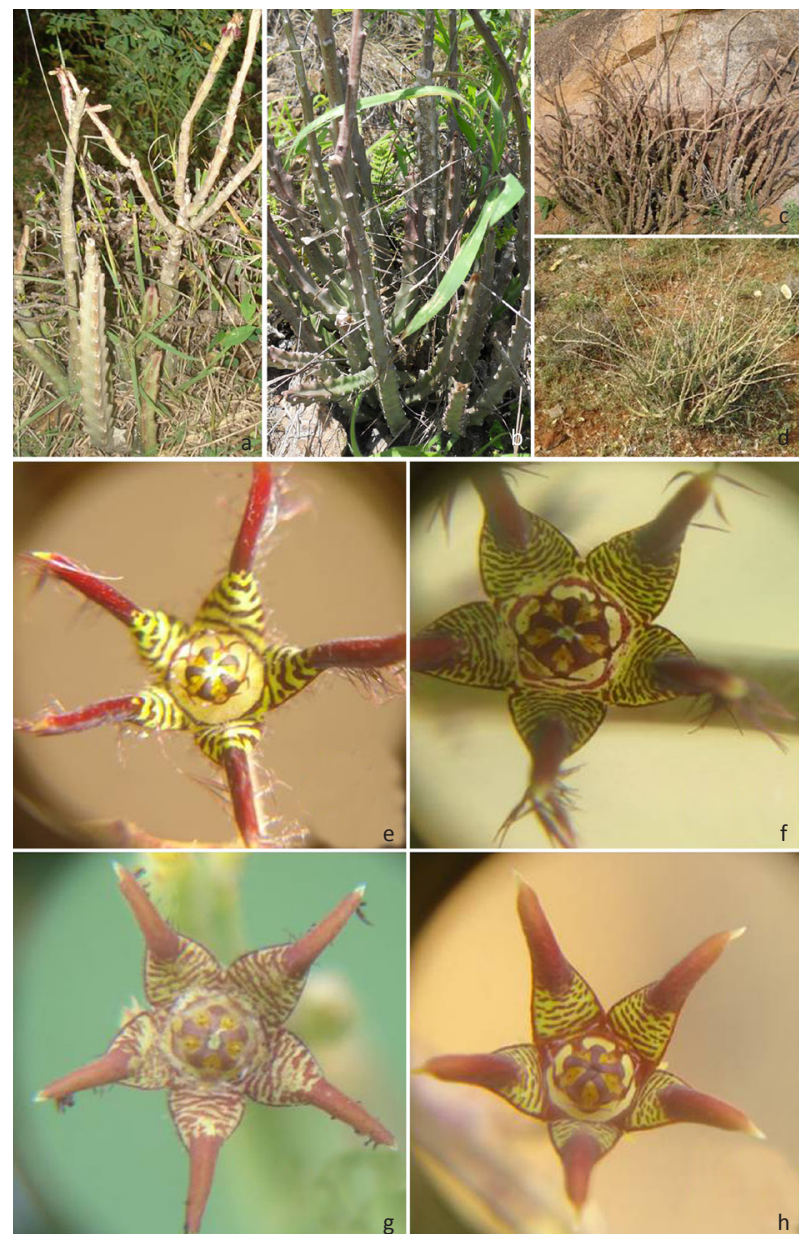

Image 2. Variation in Caralluma adscendens var. attenuata (Wight) Grav. \& Mayur.

A - habitat with thorny associates; B - habitat on road sides; C - habitat on rocky substratum; D - open bush; E-H - floral variations (@ S. Karuppusamy \& K.M. Prabhu).

Aditya, S. (2011b). Caralluma sarkariae var. longipedicellata var. nova A new Caralluma variety from Peninsular India. Asklepias 110: 18-24.

Bruyns, P.V. (1989). Miscellaneous notes on Stapelieae (Asclepiadaceae). Bradleya 7: 63-68.

Gilbert, M.G. (1990). A review of Caralluma R. Br. and its segregates. Bradleya 8: 1-32.

Gravely, F.H. \& P.V. Mayuranathan (1931). The Indianspecies of the genus Caralluma (Fam. Asclepiadaceae). Bulletin of Madras Government Museum 4: 1-28.

Jagtap, A. \& N.P. Singh (1999). Fasicles of flora of India. Botanical Survey of India, Calcutta 24: 190-210.

Karuppusamy, S. \& T. Pullaiah (2007). Two New Varieties of Caralluma stalagmifera C.E.C. Fisch. (Asclepiadaceae) from Peninsular India. Rheedea 17(1-2): 41-45.

Karuppusamy, S., A. Ugraiah \& T. Pullaiah (2012). Morphological and reproductive variations within Boucerosia umbellata complex (Family: Apocynaceae, subfamily: Asclepiadoideae). The International Journal of Plant Reproductive Biology 4: 53-60.

Karuppusamy, S., A. Ugraiah \& T. Pullaiah (2013). Caralluma (sensu lato) - Antiobesity plants. Astral International Publishers, New Delhi, India, 284pp.

Kumar, A.S., S. Kavimani \& K.N. Jayaveera (2011). A review on medicinal plant with potential antibiotic activity. International Journal of Pharmacology 2(2): 53-60.

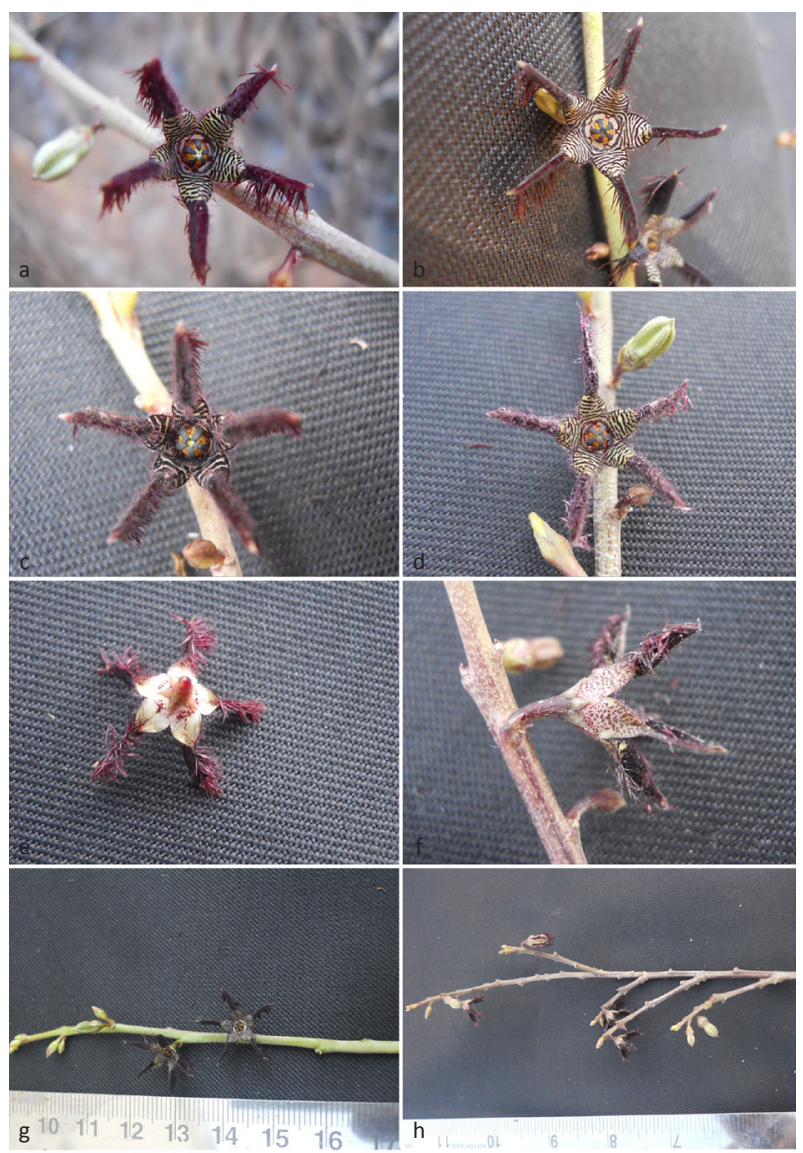

Image 3. Variation in Caralluma adscendens (Roxb.) Haw. var. attenuata (Wight) Grav. \& Mayur.

A-D - flower colour variation; $E-F$ - variation in ornamentation in lower side of corolla lobes; G-H - variation in branching pattern of inflorescence (@ K.M. Prabhu).

Mabberley, D.J. (1993). The Plant Book. Cambridge University Press. Cambridge, 126pp.

Madhuri, V., V. Amrutha, Audipudi \& K.S.R. Murthi (2010). Evaluation of immuno-stimulating activities of Caralluma spp. International Journal of Pharmacognosy and Phytochemical Research 2(4): 1-4.

Maruthupandian, A. \& V.R. Mohan (2010). Observation of ethanomedicinal plants from Sirumalai Hills in Western Ghats of Tamil Nadu, India. Journal of Herbal Medicine and Taxicology 4(2): 89-92.

Meve, U. \& S. Liede (2002). A molecular phylogeny and generic rearrangement of the stapelioid Ceropegieae (ApocynaceaeAsclepiadoideae). Plant Systematics and Evolution 234(1-4): 171-209; http://dx.doi.org/10.1007/s00606-002-0220-2

Meve, U. \& S. Liede (2004). Subtribal division of Ceropegieae (Apocynaceae: Asclepiadoideae). Taxon 53(1): 61-72.

Plowes, D. (1995). A reclassification of Caralluma R. Br. (Stepelieae: Asclepiadaceae). Haselotnia 3: 49-70.

Plowes, D. (2011). When is a Caralluma not a Caralluma? Asklepias 107: 3-22.

Ramachandran, V.S., S. Joseph, H.A. John \& C. Sofiya (2011). Caralluma bicolor sp. nov. (Apocynaceae, Asclepiadoideae) from India. Nordic Journal of Botany 29(4): 447-450; http://dx.doi.org/10.1111/j.17561051.2011.01041.x

Reddy, K.N., G. Trimurthulu \& C.S. Reddy (2010). Plant used by the ethnic people of Krishna District, Andhra Pradesh. International Journal of Traditional Knowledge 9: 313-317.

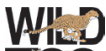

